International Journal of Forensic Science \& Pathology (IJFP)

ISSN 2332-287X

\title{
Neurobiological Basis of Reactive Aggression: A Review
}

Shiina A

Department of Psychiatry, Chiba University Hospital, Chiba, Japan.

\begin{abstract}
Reactive aggression is a response to salient threats that may have evolved as a strategy for survival. The likelihood of its outburst is mediated by several factors including the activity of serotonin and other neurotransmitters that regulate reactive aggression through the corticolimbic circuit. Specifically, this circuit is modulated by monoamine oxidase A (MAOA) such that low levels of activity incline an animal to impulsive behavior. Evidence also indicates that aggressive behavior is determined through interactions between genes and the environment. Further studies are expected for appropriate treatment.
\end{abstract}

Keywords: Reactive Aggression; Serotonin; Monoamine Oxidase A (MAOA); Gene-Environment Interaction.

\section{*Corresponding Author:}

Akihiro Shiina, MD, PhD,

Department of Psychiatry, Chiba University Hospital, Chiba, Japan.

E-mail: shiina-akihiro@faculty.chiba-u.jp

Recieved: January 10, 2015

Accepted: March 26, 2015

Published: March 27, 2015

Citation: Shiina A (2015) Neurobiological Basis of Reactive Aggression: A Review. Int J Forensic Sci Pathol. 3(3), 94-98. doi: http://dx.doi. org/10.19070/2332-287X-1500023

Copyright: Shiina $\mathbf{A}^{\odot}$ 2015. This is an open-access article distributed under the terms of the Creative Commons Attribution License, which permits unrestricted use, distribution and reproduction in any medium, provided the original author and source are credited.

\section{Introduction}

Aggression is defined as any form of behavior that is intended to injure someone physically or psychologically [1]. While aggression was seen as a homogeneous category of behavior until the 1960s, evidence has since suggested that it can be divided into two subtypes: proactive and reactive $[2,3]$.

Proactive (instrumental, predatory, cold-blooded, or premeditated) aggression is a controlled attack designed to achieve a goal, such as acquiring money or social dominance over others. Individuals engaged in proactive aggression are consciously aware of the benefits gained from using violence [4]. In contrast, reactive (impulsive, affective, hostile, or hot-blooded) aggression is a physical act committed with little consideration of its consequences or harm to others, and is often accompanied by feelings of remorse or thought confusion [5]. Assessment is performed through measurements that have been developed to quantify the magnitude of each form of aggression $[6,7]$.

Support for categorizing aggression this way is not universal.
Some believe that such a dichotomy overlooks multifaceted motivations that drive human violence, and others point out that most children who frequently use one form of aggression also frequently use the other [8]. However, distinguishing between reactive and proactive aggression has several advantages. In child inpatients, future antisocial behavior is more strongly related to proactive aggression than to reactive aggression [9]. Additionally, increases in proactive, but not reactive, aggressive behavior in young teenagers partially predicts later delinquency within a few years [10]. Furthermore, when proactive aggression is observed in adolescent boys, it also predicts psychopathic characteristics in adulthood. In contrast, reactive aggression in adolescent boys is specifically associated with negative emotions such as anxiety [11]. A meta-analysis has shown that internalizing problems [12], suicidal ideation, and suicidal behavior [13] are more strongly related to reactive aggression than to proactive aggression. These findings support the idea that aggressive behaviors exist in two fundamentally different forms, and as a corollary, that effective interventions for reactive aggression should be different from those for proactive aggression.

\section{Reactive Aggression As A Dysfunction}

The neural circuitry governing outbursts of reactive aggression has been investigated using mammalian species [14]. Based on the results, reactive aggression is now understood to be a part of a system that responds to acute threats. Low levels of threat trigger freezing, whereas high levels lead to escape-related behavior. However, a high-level threat without any possibility of flight will elicit reactive aggression $[15,16]$. Thus, reactive aggression can be an alternative adaptive response to a threatening stimulus [17].

While reactive aggression can be natural and beneficial in some situations, it can be a dysfunction when frequently exhibited in inappropriate situations. Several studies have tried to explain this phenomenon as an inability to inhibit violent impulses when frustrated. This hypothesis is consistent with findings that subjects 
displaying reactive aggression also show executive dysfunctions such as exaggerated perception of hostility from others [18], impaired somatic marker systems [19], and social response reversal [20]. Furthermore, patients who displayed antisocial behavior showed impaired performance on measures of executive functioning $[21,22]$. Similar dysfunctions are also observed in psychopathic patients who also are at high risk for both reactive and proactive aggression [23]. In short, reactive aggression likely results from both excessive responses to stimuli and deficits in correctly interpreting stimuli and making decisions based on them.

\section{Neuronal Circuit For Reactive Aggression}

Animal studies have indicated that responses to imminent threats are mediated by a system that runs from the amygdala (AMG) downward, largely via the stria terminalis to the medial hypothalamus $(\mathrm{MH})$, and from there to the dorsal half of the periaqueductal gray (PAG) $[14,23$,24]. This AMG-MH-PAG hierarchical pathway is also found in humans. One theory is that the AMG acts as a mediator that can increase or decrease the responsiveness of the sub-cortical systems that respond to threats. Thus, lesions to the AMG can modulate the risk of reactive aggression [25]. However, studying this pathway directly is still challenging, partially because of technical difficulties in visualizing neural activity in sub-cortical regions of the human brain [25].

Ever since the well-known case in which Phineas Gage showed a remarkable personality change after severe frontal lobe injury, it has been hypothesized that dysfunction in the frontal lobe might contribute to aggressive behavior [26, 27]. Indeed, several lines of evidence indicate that frontal cortex is involved in the modulation of the AMG-MH-PAG pathway [14, 28, 29]. Animal studies show that the AMG and medial prefrontal cortex are connected by a negative regulatory circuit $[30,31]$. Disrupting this circuit causes deficits in emotion regulation,which results in impulsive behaviors [23]. Moreover, neuroimaging studies using positron emission tomography indicate frontal lobe dysfunction in patients displaying reactive aggression. Lower glucose metabolic values were observed in medial temporal and prefrontal cortices of violent patients than of control subjects [32]. Affective murderers also showed decreased activity in bilateral prefrontal cortices, but increased activity in right subcortical areas [4]. It is noteworthy that the same findings were not observed in people who exhibited predominantly proactive aggression. Dysfunctions in the ventromedial prefrontal cortex [29] and the orbital frontal cortex (OFC) [20] were shown to be associated with a higher risk for reactive aggression but not proactive aggression [16]. In contrast, the dorsolateral prefrontal cortex does not seem to have a prominent role in reactive aggression [25], although room for argument still exists [33].

The OFC modulates reactive aggression via the AMG-MH-PAG pathway through at least two separate processes. First, it computes expected rewards that accompany actions. If a reward is absent or less than expected, some OFC neurons increase their activity and excite sub-cortical systems, which may lead to reactive aggression [34]. Second, the OFC is involved in social response reversal [20]. Patients with OFC deficits have difficulty suspending ongoing behavior even though they recognize that other people are expressing anger or unfriendly emotions [20, 35].

Furthermore, the AMG and OFC are tightly connected by several pathways that are functionally linked with each other [30, 36]. Patients with intermittent explosive disorder exhibited exaggerated AMG reactivity and diminished OFC activity, but did not show AMG-OFC coupling, suggesting that their disconnection from each other caused difficulty in modulating aggression in social settings [37].

\section{Biochemicals In Reactive Aggression}

The risk of reactive aggression is higher in clinical conditions such as posttraumatic stress disorder [38, 39], anxiety disorder [40], childhood bipolar disorder [41], and impulse-control disorder. Some have hypothesized that serotonin is involved in modulating reactive aggression because abnormal neurotransmitter levels is a common root of these disorders [42].

Serotonin is a monoamine neurotransmitter derived from tryptophan that has an important role in the central nervous system. Lowered concentrations of 5-hydroxyindoleacetic (5-HT) acid, the main metabolite of serotonin, were observed in impulsively violent offenders, but not in those who were proactively violent [43]. In healthy volunteers, the effects of tryptophan depletion included an increase in aggression, which suggests that aggression is one consequence of impeding synthesis of serotonin in the brain [44]. In contrast, administering the selective serotonin reuptake inhibitor paroxetine resulted in a reduction of hostility in a double-blind trial [45]. These results are consistent with clinical observations that agitated patients had an estimated shortage of serotonin $[38,39,40]$. However, the correlation between serotonin and violence is not quite simple. Several subtypes of serotonin receptors exist in multiple regions of the brain, often with differing functions. For example, activation of 5-HT1A and 5 -HT1B receptors in mesocorticolimbic areas triggers a reduction in aggressive behaviors, whereas activating them in the medial prefrontal cortex or septal area can cause aggression [46].

Some hormones are also involved in the regulation of aggressive behavior. Testosterone level has repeatedly been shown to be associated with reactive aggression in both men and women [47-49]. Conversely, low levels of cortisol have been observed in subjects with violently aggressive, antisocial tendencies $[50,51]$. These findings suggest that reactive aggression is affected by an imbalance between testosterone and cortisol at the subcortical level [17]. In addition, the so-called social neuropeptides vasopressin and oxytocin are also likely to play a role in mediating impulsiveness [52].

\section{The Maoa Gene And Reactive Aggression}

Genetic factors have also been implicated in susceptibility to aggressive behavior [53]. Brunner's landmark work described a large group of related Dutch in which many people (all males) were affected by a syndrome consisting of borderline mental retardation and impulsive aggression. The work proved that a specific genetic variant was involved in the aggressive behavior, and the syndrome is now called Brunner syndrome [54]. The common factor linking all people with the syndrome was a total lack of MAOA activity. In each of five males, a point mutation was identified in the eighth exon of the MAOA structural gene. These findings had a great impact on sequential genetic research.

MAO catalyzes the oxidative deamination of biogenic amines. 
The two isoforms (MAOA and MAOB) are localized to the outer mitochondrial membrane in the presynaptic terminal of monoamine projection neurons and in astrocytes, where they are positioned to regulate the amount of intracellular substrate available for release and the degree of monoamine inactivation [53]. While MAOB primarily metabolized dopamine, MAOA also metabolizes serotonin and norepinephrine. Therefore, genetic variation in the MAOA gene may cause disruption at serotonergic synapses. Although Brunner syndrome is rare, many common polymorphic variants have been identified in the MAOA gene region. Among them, a variable number of tandem repeat (VNTR) polymorphisms located in the promoter region of the gene have been the most widely studied. The MAOA upstream VNTR comprises a 30 -bp sequence that is repeated 2, 3, 3.5, 4, or 5 times [55]. Higher expression linked to 3.5 or 4 repeats is referred to as MAOA-H, and is related to normal enzymatic activity, while 3 repeats or less are referred to as MAOA-L and is associated with reduced MAOA activity [56].

A wealth of evidence in animal research suggests that MAOA is an important biological regulator of aggressive behavior. MAOA knockout mice exhibited frequent reactive aggression [57]. Serotonin concentration was increased up to nine times in the brains of isolated transgenic mice in which transgene integration caused a deletion of the gene encoding MAOA [58]. Additionally, MAOA knockout mice lack the characteristic barrel-like clustering of layer IV neurons in the primary somatosensory cortex [59]. It is likely that some change in serotonin function occurs in the MAOA gene-deficient mice [46]. Intriguingly, with early administration of a serotonin-synthesis inhibitor, the mice restored the formation [59]. This result suggests that the impact of genetic risk might be mitigated during critical periods in youth and early adolescence [53]. This lends credence to the importance of gene-environment interactions in modulating aggressive behavior, and shows the potential benefits of early intervention for at-risk subjects.

The MAOA-L gene has been linked to aggressive behavior in humans [60]. A meta-analysis showed that MAOA-L was significantly associated with antisocial behaviors [61]. The importance of MAOA genetic variation in determining aggressive behavior is consistent with the fact that most violent criminals are male. Because the MAOA gene is linked to the $\mathrm{X}$ chromosome, men only need one copy of the MAOA-L gene to be affected, while women are affected only if both alleles contain the abnormal MAOA gene [60]. The relationship between MAOA gene variations and aggression in women is still controversial [62].

Few studies investigating the MAOA gene definitively distinguish reactive aggression from proactive aggression [63]. Evidence suggests MAOA-L is associated with aggressive reactions in highly provocative situations $[63,64]$. In contrast, no evidence decisively indicates that proactive aggression is dominant in subjects with MAOA-L. MAOA gene variation may therefore be associated with impulsivity rather than antisocial behavior itself.

Supporting evidence comes from investigating what happens in brains of male carriers of the MAOA-L gene. The subjects showed a pattern of enhanced AMG activation and lower cortical volume $[65,66]$. Dorsal anterior cingulate cortex, which is associated with rejection-related distress, is activated in MAOA-L individuals $[67,68]$. It is highly likely that this imbalance within the corticolimbic circuit is the cause of disrupted emotion regulation. Recently, the interaction between the MAOA gene and the en- vironment has become a hot topic. Maltreated children with an MAOA-L genotype were more likely to develop antisocial behavior [69] than those who were not maltreated. This finding was replicated by several studies [70] and substantiated by two metaanalyses [71, 72]. Successful visualization of altered brain structure and function in maltreated children with MAOA-L should be the next step in studying this issue, as well as assessing interventions that might reduce their risk of developing aggressive tendencies [67].

\section{Conclusion}

Reactive aggression has been attracting attention of many professionals in not only forensic science and criminal justice, but behavioral biology. Among recent studies, the results regarding the MAOA gene and gene-environment relationship greatlycontributed to the deep understanding of this antisocial, but originally functional phenomenon. In the near future, it is expected to apply these findings to the treatment setting. For example, children identified as high-risk may be educationally intervened in the early stage so that subsequent aggressive behaviors would be prevented. On the other hand, the clarification of the biological basis of reactive aggression is possible to visualize the effect of behavioral therapy, leading to further development of the psychological interventional technique. Collaboration of professionals with several backgrounds can reduce the victims of violence through utilizing the scientific research.

\section{References}

[1]. Berkowitz L (1993) Aggression: Its Causes, Consequences, and Control. McGraw-Hill, New york.

[2]. Kempes M, Matthys W, de Vries H, van Engeland H (2005) Reactive and proactive aggression in children--a review of theory, findings and the relevance for child and adolescent psychiatry. European Child and Adolescent Psychiatry 14(1): 11-19.

[3]. Vitaro F, Brendgen, M, Tremblay R E (2002) Reactively and proactively aggressive children: antecedent and subsequent characteristics. Journal of Child Psychology and Psychiatry 43(4): 495-505.

[4]. Raine A, Meloy JR, Bihrle S, Stoddard J, LaCasse L, et al.(1998) Reduced prefrontal and increased subcortical brain functioning assessed using positron emission tomography in predatory and affective murderers. Behavioral Sciences \& the Law 16(3): 319-332.

[5]. Barratt ES, Stanford MS, Dowdy L, Liebman MJ, Kent TA (1999) Impulsive and premeditated aggression: a factor analysis of self-reported acts. Psychiatry Research 86(2): 163-173.

[6]. Brown K, Atkins MS, Osborne ML, Milnamow M (1996) A revised teacher rating scale for reactive and proactive aggression. Journal of Abnormal Child Psychology 24(4): 473-480.

[7]. Raine A, Dodge K, Loeber R, Gatzke-Kopp L, Lynam D, et al.(2006) The Reactive-Proactive Aggression Questionnaire: Differential Correlates of Reactive and Proactive Aggression in Adolescent Boys. Aggressive Behavior 32(2): 159-171.

[8]. Bushman BJ, Anderson CA (2001) Is it time to pull the plug on the hostile versus instrumental aggression dichotomy? Psychology Review 108(1): 273 279.

[9]. Fite P J, Stoppelbein L, Greening L (2009) Proactive and reactive aggression in a child psychiatric inpatient population. Journal of Clinical Child and Adolescent Psychology 38(2): 199-205.

[10]. Fite P J, Colder C R, Lochman J E, Wells KC (2008). Developmental trajectories of proactive and reactive aggression from fifth to ninth grade. Journal of Clinical Child and Adolescent Psychology 37(2): 412-421.

[11]. Fite PJ, Raine A, Stouthamer-Loeber M, Loeber R, Pardini D A (2009) Reactive and Proactive Aggression in Adolescent Males: Examining Differential Outcomes 10 years Later in Early Adulthood. Criminal Justice and Behavior 37(2): 141-157.

[12]. Card NA, Little TD (2006) Proactive and reactive aggression in childhood and adolescence: A meta-analysis of differential relations with psychosocial adjustment. International Journal of Behavioral Development 30(5): 466480. 
[13]. Conner KR, Duberstein PR, Conwell Y, Caine ED (2003) Reactive aggression and suicide Theory and evidence. Aggression and Violent Behavior 8(4): 413-432.

[14]. Gregg TR, Siegel A (2001) Brain structures and neurotransmitters regulating aggression in cats: implications for human aggression. Progress in NeuroPsychopharmacology \& Biological Psychiatry 25(1): 91-140.

[15]. Blair RJ (2001) Neurocognitive models of aggression, the antisocial personality disorders, and psychopathy. Journal of Neurology, Neurosurgery and Psychiatry 71(6): 727-731.

[16]. Blair J, Mitchell D, Blair K (2005) The Psychopath: Emotion and the Brain. Wiley-Blackwell, London.

[17]. van Honk J, Harmon-Jones E, Morgan BE, Schutter, DJ (2010) Socially explosive minds: the triple imbalance hypothesis of reactive aggression. Journal of Personality 78(1): 67-94

[18]. Crick NR, Dodge KA(1996) Social information-processing mechanisms in reactive and proactive aggression. Child Development 67(3): 993-1002.

[19]. Bechara A, Damasio, H, Damasio AR (2000) Emotion, decision making and the orbitofrontal cortex. Cerebral Cortex 10(3): 295-307.

[20]. Blair RJ, Cipolotti L (2000). Impaired social response reversal. A case of 'acquired sociopathy'. Brain 123(6): 1122-1141.

[21]. Krakowski M, Czobor P, Carpenter MD, Libiger J, Kunz M, et al. (1997) Community violence and inpatient assaults: neurobiological deficits. Journal of Neuropsychiatry and Clinical Neuroscience 9(4): 549-555.

[22]. Morgan AB, Lilienfeld SO (2000) A meta-analytic review of the relation between antisocial behavior and neuropsychological measures of executive function. Clinical Psychology Review 20(1): 113-136.

[23]. Blair RJ (2010) Psychopathy, frustration, and reactive aggression: the role of ventromedial prefrontal cortex. British Journal of Psychology 101(3): 383399.

[24]. Blair R J (2004). The roles of orbital frontal cortex in the modulation of antisocial behavior. Brain Cognition 55(1): 198-208.

[25]. van Elst LT, Woermann FG, Lemieux L, Thompson P J, Trimble M R (2000) Affective aggression in patients with temporal lobe epilepsy: a quantitative MRI study of the amygdala. Brain 123(2): 234-243.

[26]. Damasio H, Grabowski T, Frank R, Galaburda AM, Damasio AR (1994) The return of Phineas Gage: clues about the brain from the skull of a famous patient. Science 264(5162): 1102-1105.

[27]. O'Driscoll K, Leach JP (1998) "No longer Gage": an iron bar through the head. Early observations of personality change after injury to the prefrontal cortex. BMJ 317(7174): 1673-4.

[28]. Grafman J, Schwab K, Warden D, Pridgen A, Brown H R, et al. (1996) Frontal lobe injuries, violence, and aggression: a report of the Vietnam Head Injury Study. Neurology 46(5): 1231-1238.

[29]. Anderson SW, Bechara A, Damasio H, Tranel D, Damasio AR (1999) Impairment of social and moral behavior related to early damage in human prefrontal cortex. Nature Neuroscience 2(11): 1032-1037.

[30]. Amaral DG, Price JL (1984). Amygdalo-cortical projections in the monkey (Macaca fascicularis). The Journal of Comparative Neurology 230(4): 465496

[31]. Cavada C, Compañy T, Tejedor J, Cruz-Rizzolo R J, Reinoso-Suárez F (2000) The anatomical connections of the macaque monkey orbitofrontal cortex. A review. Cereb Cortex 10(3): 220-242.

[32]. Volkow ND, Tancredi LR, Grant C, Gillespie H, Valentine A, et al. (1995) Brain glucose metabolism in violent psychiatric patients: a preliminary study. Psychiatry Research 61(4): 243-253

[33]. Goyer PF, Andreason PJ, Semple WE, Clayton AH, King AC, et al. (1994) Positron-emission tomography and personality disorders. Neuropsychopharmacology 10(1): 21-28.

[34]. Rolls ET (2000) The orbitofrontal cortex and reward. Cereb Cortex 10(3): 284-294.

[35]. Blair RJ, Morris JS, Frith CD, Perrett DI, Dolan RJ (1999) Dissociable neural responses to facial expressions of sadness and anger. Brain 122(5): 883-893.

[36]. Price JL (2003) Comparative aspects of amygdala connectivity. Annals of the New York Academy of Sciences 985: 50-58.

[37]. Coccaro EF, McCloskey MS, Fitzgerald DA, Phan KL (2007) Amygdala and orbitofrontal reactivity to social threat in individuals with impulsive aggression. Biological Psychiatry 62(2): 168-178.

[38]. Marsee MA (2008) Reactive aggression and posttraumatic stress in adolescents affected by Hurricane Katrina. Journal of Clinical Child and Adolescent Psychology 37(3): 519-529.

[39]. McLott J, Jurecic J, Hemphill L, Dunn KS (2013) Development of an amygdalocentric neurocircuitry-reactive aggression theoretical model of emergence delirium in posttraumatic stress disorder: an integrative literature review. AANA Journal 81(5): 379-384.

[40]. Bubier JL, Drabick DA (2009) Co-occurring anxiety and disruptive behavior disorders: the roles of anxious symptoms, reactive aggression, and shared risk processes. Clinical Psychology Review 29(7): 658-669.
[41]. Barzman DH, DelBello MP, Adler CM, Stanford KE, Strakowski, SM (2006) The efficacy and tolerability of quetiapine versus divalproex for the treatment of impulsivity and reactive aggression in adolescents with cooccurring bipolar disorder and disruptive behavior disorder(s). Journal of Child and Adolescent Psychopharmacology 16(6): 665-670.

[42]. Lee R, Coccaro E (2001) The neuropsychopharmacology of criminality and aggression. Canadian Journal of Psychiatry 46(1): 35-44.

[43]. Linnoila M, Virkkunen M, Scheinin M, Nuutila A, Rimon R, et al. (1983) Low cerebrospinal fluid 5-hydroxyindoleacetic acid concentration differentiates impulsive from nonimpulsive violent behavior. Life Science 33(26): 2609-2014.

[44]. Bell C, Abrams J, Nutt D (2001) Tryptophan depletion and its implications for psychiatry. British Journal of Psychiatry178: 399-405.

[45]. Knutson B, Wolkowitz OM, Cole SW, Chan T, Moore EA, et al. (1998) Selective alteration of personality and social behavior by serotonergic intervention. American Journal of Psychiatry 155(3): 373-379.

[46]. Takahashi A, Quadros IM, de Almeida RM, Miczek KA (2011) Brain serotonin receptors and transporters: initiation vs. termination of escalated aggression. Psychopharmacology (Berl) 213(2-3): 183-212.

[47]. Denson TF, Mehta PH, Ho Tan D (2013) Endogenous testosterone and cortisol jointly influence reactive aggression in women. Psychoneuroendocrinology 38(3): 416-424.

[48]. Dabbs JM, Carr TS, Frady RL, Riad JK(1995) Testosterone, crime, and misbehavior among 692 male prison inmates. Personality and Individual Differences 18(5): 627-33.

[49]. Carré JM, McCormick CM, Hariri AR (2011) The social neuroendocrinology of human aggression. Psychoneuroendocrinology 36(7): 935-944.

[50]. Virkkunen M (1985) Urinary free cortisol secretion in habitually violent offenders. Acta Psychiatrica Scandinavica 72(1): 40-44.

[51]. Vanyukov MM, Moss HB, Plail JA, Blackson T, Mezzich AC, et al. (1993) Antisocial symptoms in preadolescent boys and in their parents: associations with cortisol. Psychiatry Research 46(1): 9-17.

[52]. Heinrichs M, Domes G (2008). Neuropeptides and social behaviour: effects of oxytocin and vasopressin in humans. Progress in Brain Research 170: 337-350.

[53]. Dorfman HM, Meyer-Lindenberg A, Buckholtz JW (2014) Neurobiological mechanisms for impulsive-aggression: the role of MAOA. Current Topics of Behavioral Neurosciences 17: 297-313.

[54]. Brunner HG, Nelen M, Breakefield XO, Ropers HH, van Oost BA (1993) Abnormal behavior associated with a point mutation in the structural gene for monoamine oxidase A. Science 262(5133): 578-580.

[55]. Sabol SZ, Hu, S, Hamer D (1998) A functional polymorphism in the monoamine oxidase A gene promoter. Human Genetics 103(3): 273-279.

[56]. Syagailo YV, Stöber G, Grässle M, Reimer E, Knapp M, et al. (2001) Association analysis of the functional monoamine oxidase A gene promoter polymorphism in psychiatric disorders. American Journal of Medical Genetetics 105(2): 168-171

[57]. Scott AL, Bortolato M, Chen K, Shih JC (2008) Novel monoamine oxidase A knockout mice with human-like spontaneous mutation. Neuroreport 19(7): 739-743.

[58]. Cases O, Seif I, Grimsby J, Gaspar P, Chen K, et al. (1995) Aggressive behavior and altered amounts of brain serotonin and norepinephrine in mice lacking MAOA. Science 268(5218): 1763-1766.

[59]. Cases O, Vitalis T, Seif I, De Maeyer E, Sotelo C, et al. (1996) Lack of barrels in the somatosensory cortex of monoamine oxidase A-deficient mice: role of a serotonin excess during the critical period. Neuron 16(2): 297-307.

[60]. Hunter P (2010) The psycho gene. EMBO Reports 11(9): 667-669.

[61]. Ficks CA, Waldman ID (2014) Candidate genes for aggression and antisocial behavior: a meta-analysis of association studies of the 5HTTLPR and MAOA-uVNTR. Behavior Genetics 44(5): 427-444.

[62]. Verhoeven FE, Booij L, Kruijt AW, Cerit H, Antypa N, et al. (2012) The effects of MAOA genotype, childhood trauma, and sex on trait and statedependent aggression. Brain and Behavior 2(6): 806-813.

[63]. Kuepper Y, Grant P, Wielpuetz C, Hennig J (2013) MAOA-uVNTR genotype predicts interindividual differences in experimental aggressiveness as a function of the degree of provocation. Behavioral Brain Research 15(247): 73-78.

[64]. McDermott R, Tingley D, Cowden J, Frazzetto G, Johnson DD (2009) Monoamine oxidase A gene (MAOA) predicts behavioral aggression following provocation. Proceeding of the National Academy of Science of the United States of America 106(7): 2118-2123.

[65]. Meyer-Lindenberg A, Buckholtz JW, Kolachana B, R Hariri A, Pezawas L, et al. (2006). Neural mechanisms of genetic risk for impulsivity and violence in humans. Proceeding of the National Academy of Science of the United States of America 103(16): 6269-6274.

[66]. Cerasa A, Cherubini A, Quattrone A, Gioia MC, Magariello A, et al. (2010) Morphological correlates of MAO A VNTR polymorphism: new evidence from cortical thickness measurement. Behavioural Brain Research 211(1): 
$118-124$.

[67]. Denson TF, Dobson-Stone C, Ronay R, von Hippel W, Schira MM (2014) A Functional Polymorphism of the MAOA Gene Is Associated with Neural Responses to Induced Anger Control. Journal of Cognitive Neuroscience 26(7): 1418-1427.

[68]. Eisenberger NI, Way BM, Taylor SE, Welch WT, Lieberman MD (2007) Understanding genetic risk for aggression: clues from the brain's response to social exclusion. Biological Psychiatry 61(9): 1100-1108.

[69]. Caspi A, McClay J, Moffitt TE, Mill J, Martin J, et al. (2002) Role of genotype in the cycle of violence in maltreated children. Science 297(5582):,
851-854.

[70]. Frazzetto G, Di Lorenzo G, Carola V, Proietti L, Sokolowska E, et al. (2007) Early trauma and increased risk for physical aggression during adulthood: the moderating role of MAOA genotype. PLoS One 2(5): e486.

[71]. Taylor A, Kim-Cohen J (2007) Meta-analysis of gene-environment interactions in developmental psychopathology. Development and Psychopathology 19(4): 1029-1037.

[72]. Byrd AL, Manuck SB (2013) MAOA, Childhood Maltreatment, and Antisocial Behaviour: Meta-analysis of a Gene-Environment Interaction. Biol Psychiatry 175(1): 9-17. 